\title{
Eco-innovations and Their Role in Contemporary Business
}

doi: http://dx.doi.org/10.12775/JCRL.2020.004

\author{
MiKOŁAJ ŚLĘZAK \\ The Faculty of Economic Sciences and Management, Nicolaus \\ Copernicus University in Toruń, Poland \\ e-mail: mikolaj.slezak@wp.pl
}

\begin{abstract}
Eco-innovations become a more and more significant aspect in management theory and business practice. The concept is considered to be a solution linking the ideas of corporate social responsibility (CSR) and innovation. The aim of the study is to discuss the eco-innovations concept and their role in contemporary business. In order to meet the aim of the paper, the following operational objectives were indicated: (1) to present and discuss definitions of the eco-innovations concept; (2) to exemplify different types, antecedents and dimensions of eco-innovations; (3) to identify benefits of eco-innovations; (4) to consider eco-innovations as a source of potential competitive advantage. This study is based on the methodology of systematic literature review. The article exemplifies the definitions of eco-innovations, their types, antecedents and different dimensions. Later, it is discussed the role of eco-innovations in building the competitive advantage. The study confirms that eco-innovations can generate benefits for businesses and their environment. Thus, the role of eco-innovations in contemporary business can be considered as significant.
\end{abstract}

Keywords: eco-innovation, green innovation, CSR, innovation, systematic literature review. 


\section{Introduction}

Eco-innovations become a more and more significant aspect in management theory and business practice. Lis and Sudolska (2018) indicate eco-innovations as one of the types of socially responsible innovations. This concept is considered to be a solution linking the ideas of corporate social responsibility (CSR) and innovation. According to Carrillo-Hermosilla et al. (2010), eco-innovations may be perceived as one of the ways of taking care about the environment. Thus, they can be identified among activities conducted in accordance with the CSR concept. Eco-innovations can generate benefits for companies, societies and the natural environment, what is in accordance with the idea and assumptions of strategic CSR. Thus, eco-innovations can be considered as very significant elements of companies functioning and their strategies. As already mentioned, the idea of eco-innovations gains importance in today's business.

This concept is also more and more often studied and analyzed by the ranks of researchers in academia. Thus, an increasing stream of publications regarding the topic of eco-innovations is found in literature. However, still there can be identified some gaps in the field, which are not sufficiently analyzed. The role of eco-innovations in contemporary business is an example of such a gap. The author decided to restrict the scope of the study to theoretical analysis only as there is a lack of similar and relevant studies in literature. Searching for literature reviews regarding eco-innovations (title search for phrases 'eco-innovation' OR 'ecoinnovation' AND 'review') in the Scopus database provided unsatisfactory results. The identified publications were insufficient and most of them were out of date. Thus, it was decided that theoretical analysis on the role of eco-innovations in contemporary business would be a relevant contribution to developing the idea of eco-innovations.

The aim of the paper is to discuss the eco-innovations concept and its role in contemporary business. In order to meet the aim of the study, the following operational objectives were indicated: (1) to present and discuss definitions of the eco-innovations concept; (2) to exemplify different types, antecedents and dimensions of eco-innovations; (3) to identify benefits of eco-innovations; (4) to consider eco-innovations as a source of potential competitive advantage.

The structure of the article is divided into five parts. The first one is this introduction. The next one is the methodology section, 
explaining the method of study and the research sampling process. The third part describes the idea of eco-innovations and it studies what differs eco-innovations from traditional innovations. There are also presented various types of eco-innovations, as well as drivers and motivators for their implementation. Next, different dimensions and determinants of eco-innovations are provided. Then, consumer behaviors driving and hampering eco-innovation adoption are studied. Finally, a short guide on how to manage the development of a new environment-friendly product and its role in building a competitive advantage is exemplified.

\section{Method of study}

The systematic literature review methodology was chosen as a study method, as it seems to be the most relevant approach for qualitative mapping of a research field (Czakon, 2011). The systematic literature review methodology is very often used by authors publishing in the Journal of Corporate Responsibility and Leadership (Czerniachowicz et al., 2017; Józefowicz, 2017; Ślęzak \& Jagielski, 2018).

In order to study the issue of eco-innovations, the publications, indexed in the Scopus database, dealing with this subject were identified. The research sampling process was carried out in five steps (Table 1):

(1) the alternative of phrases: 'eco-innovation' OR 'ecoinnovation' OR 'eco-innovations' OR 'ecoinnovations' was searched in article titles. 348 records were found;

(2) the results were limited to the subject area of Business, Management and Accounting. The sample was reduced to 159 items;

(3) the h-index (average number of citations) equal to 23 was chosen as cut-off point. Only publications with the number of citations equal or higher than 23 were taken into account. 24 items remained;

(4) the analysis of abstracts was conducted to identify the most relevant papers for full-text analysis. The sample was reduced to 10 publications;

(5) the sample was increased by snowball sampling. Finally, the sample numbered 15 publications. 
Table 1. Research sampling process

\begin{tabular}{ll}
\hline Stage & $\begin{array}{l}\text { Publications } \\
\text { [N] }\end{array}$ \\
\hline Records identified in the Scopus database through title search & 348 \\
\hline Records identified through limiting the subject area & 159 \\
\hline $\begin{array}{l}\text { Records identified through excluding publications of the number of } \\
\text { citations lower than h-index }\end{array}$ & 24 \\
\hline $\begin{array}{l}\text { Records identified through abstract analysis, subject to full-text } \\
\text { analysis }\end{array}$ & 10 \\
\hline $\begin{array}{l}\text { Records identified through abstract analysis, subject to full-text } \\
\text { analysis increased by snowball sampling methodology }\end{array}$ & 15 \\
\hline
\end{tabular}

Source: own study based on data retrieved from the Scopus database.

\section{The idea of eco-innovations}

In recent years, it can be observed an increased interest in environmental issues, environmental sustainability, including such concepts as CSR. Increased expectations (e.g. taking care about the natural environment, creating shared values also for societies) towards businesses formulated from societies, push companies to respond to these needs. One of the ways of taking care about the environment can be eco-innovations, which receive more and more attention in business practice (Carrillo-Hermosilla et al., 2010). The aforementioned authors underline the relevance of eco-innovations contribution to the innovation system and its revival.

A variety of definitions of eco-innovations can be found in literature. Certainly, there is no one definition, which could explain the whole complexity of the issue. Moreover, it is important that eco-innovations can be also labeled as environmental innovations, green innovations, or sustainable innovations (Halila \& Rundquist, 2011). Below, there is provided a selection of definitions:

- "Eco-innovation is any form of innovation aiming at significant and demonstrable progress towards the goal of sustainable development, through reducing impacts on the environment or achieving a more efficient and responsible use of natural resources, including energy" (European Commission, 2007, p. 3, as cited in: Carrillo-Hermosilla et al., 2010, p. 1074); 
- "Eco-innovation is the production, assimilation or exploitation of a novelty in products, production processes, services or in management and business methods, which aims, throughout its lifecycle, to prevent or substantially reduce environmental risk, pollution and other negative impacts of resource use (including energy)" (European Commission, 2008, p. 4, as cited in: Carrillo-Hermosilla et al., 2010, p. 1074);

- "Eco-innovation is the creation of novel and competitively priced goods, processes, systems, services, and procedures designed to satisfy human needs and provide a better quality of life for all, with a life-cycle minimal use of natural resources (materials including energy, and surface area) per unit output, and a minimal release of toxic substances" (Europa INNOVA, 2006, p. 3, as cited in: Carrillo-Hermosilla et al., 2010, p. 1074);

- "Eco-innovation is the process of developing new products, processes or services which provide customer and business value but significantly decrease environmental impact" (Fussler and James, 1996, p. 364, as cited in: Carrillo-Hermosilla et al., 2010, p. 1074);

- Eco innovation is "the production, assimilation or exploitation of a product, production process, service or management or business methods that is novel to the firm (or organization) and which results, throughout its life cycle, in a reduction of environmental risk, pollution and other negative impacts of resources use (including energy use) compared to relevant alternatives” (Kemp \& Pontoglio, 2007, p. 10, as cited in: Ghisetti et al., 2015, p. 1081).

Summing up the aforementioned definitions, eco-innovation is something new in the company's operations and its aim is to reduce the environmental impact, which is caused by production and consumption. It can be also connected with a product, a process or an organization as a whole.

There are some differences between traditional innovations and eco-innovations, which are worth noting. Kesidou and Demirel (2012) analyze the OECD's definitions of those two issues and indicate two significant dissimilarities. 'Normal' innovation is related to introducing of a new or an improved product, process, marketing method, organizational method in business activities. On the other 
hand, eco-innovation "is innovation that reflects the concept's explicit emphasis on a reduction of environmental impact, whether such an effect is intended or not. And, it is not limited to innovation in products, processes, marketing methods and organizational methods, but also includes innovation in social and institutional structures" (Kesidou \& Demirel, 2012, p. 862). Another very important issue is mentioned by Ghisetti et al. (2015), who agree that environmental innovations differ from normal technological and non-technological innovations. They imply an 'win-win' effect which is crucial. It helps to combine company's competitiveness with environmental sustainability and to achieve expected growth. It is also very significant in eco-innovations' consideration that throughout increased efforts, both financial and institutional, they become an important element of the company's environmental, competitiveness and innovation strategies and policies (Ghisetti et al., 2015).

\section{Types of eco-innovations}

An innovation is related to the change or introducing completely new elements in a way of doing something. It can be distinguished two types of changes, which can be triggered by eco-innovations (Carrillo-Hermosilla et al., 2010):

- incremental changes: connected with progressive and constant changes which maintain actual production systems and keep existing networks. They create added value to the existing system where innovations are rooted. They also enhance competencies;

- radical changes: inconsecutive modifications that are related to the replacement of existing elements or even an entire system and added value creation. They are competence-destroying.

Eco-innovations encompass: product innovation, process innovation, and organizational innovation. Each type has its own determinants, attributes and contribution to environmental performance. However, Cheng et al. (2014) highlight the problem of ineffectiveness of innovation programs implemented separately. At this point, it would be relevant to look at the key aspects of the eco-innovations types identified above, relationships among them, and their impact on business performance. Eco-product innovation is related to introducing 
completely new or improved products (e.g. by adding some advanced ecologically technologies to products' components and materials). An eco-product innovation is connected rather with the way of using than the production production (Cheng et al., 2014). Eco-process innovation is about adding new components introduced to the production system for producing eco-products. It refers to "the improvement of existing production processes or the addition of new processes to reduce environmental impact” (Cheng et al., 2014, p. 85). Eco-organizational innovation does not directly impact the environment, but simplifies eco-process and eco-product innovations implementation. It adds some new and eco methods to business practices and management (Cheng et al. 2014). Business performance is affected, in a direct and indirect way, by all eco-organizational, eco-process, and ecoproduct innovations. The research results and findings exemplify that managers have to understand the interdependence level and relations between each of three types of eco-innovations to introduce effective eco-innovations programs. However, eco-organizational innovations have the most powerful impact on business performance (Cheng et al., 2014).

\section{Antecedents of eco-innovations}

A variety of antecedents of eco-innovations is observed. Doran and Ryan (2012) point that innovations can be driven by technology push (supply side) and market pull (demand side). However, eco-innovations, despite of the factors mentioned above, are also under an impact of regulations, environmental policy, and institutional and political issues. Carrillo-Hermosilla et al. (2010) refer to OECD and indicate that eco-innovation can be motivated by two factors: environmental or side-effect of other objectives, e.g. reducing costs. According to that, they identify that first can be called as "environmentally motivated innovations", and second as "environmentally beneficial normal innovations” (Carrillo-Hermosilla et al., 2010). Kesidou and Demirel (2012) indicate three key factors that can drive eco-innovations. They pool together views from the theories of innovation (and eco-innovation), CSR strategy, and environmental economics. Taking it into consideration, it can be identified three key factors driving eco-innovations, as already mentioned. These are: 
- demand factors: CSR and customer requirements (Kesidou \& Demirel, 2012; Doran \& Ryan, 2012), environmental awareness and consumers' choices of products which are environmentally friendly, expected increase in market share (Horbach et al., 2013);

- supply factors/organizational capabilities: environmental management systems (Kesidou \& Demirel, 2012), knowledge bases, human capital, R\&D activities, cost reducing, market structure (Horbach et al., 2013);

- regulation factors/stringency of environmental regulations (Kesidou and Demirel, 2012; Doran and Ryan, 2012), implementation of environmental policy instruments (Horbach et al., 2013).

Kesidou and Demirel (2012) set hypotheses related to each factor's influence on eco-innovation, which state that:

- demand factors influence the decision of the firm to invest in eco-innovations and the level of investment in eco-innovations;

- organizational factors influence the decision of the firm to invest in eco-innovations and the level of investment in eco-innovations;

- stringency of environmental regulations affect the level of investments in eco-innovations differently for less innovative firms and more innovative firms.

Kesiodu and Demirel (2012) conducted the study to check how their hypotheses deal with real business. The findings exemplify that demand factors have an influence on companies' decisions about making an investment in eco-innovations. Nevertheless, these factors (especially CSR and customer requirements) do not impact the level of investment in green innovations. The study emphasizes that firms under societal pressure make some investments in environmental innovations, however they do not commit too much resources. As regards organizational capabilities, they are very significant factors, both while taking decisions about undertaking eco-innovations activities and how much to invest. And finally, stringency of environmental regulations has an influence on green innovations when "firms respond to stricter environmental regulations with higher levels of eco-innovations" (Kesidou \& Demirel, 2012, p. 868). They also find that this last factor drives only the most innovative firms. Summing up the findings, it can be said that demand factors (CSR and customer requirements) have 
an influence on undertaking investments in eco-innovations. On the other hand, organizational capabilities and environmental regulations impact the level of investments in environmental innovations (Kesiodu \& Demirel, 2012). However, all of three factors are interdependent and any change in one factor impacts other factors (Doran \& Ryan, 2012).

\section{Implementation of eco-innovations}

In order to efficiently and effectively implement eco-innovations, understanding of their dimensions is needed. The four following dimensions of eco-innovations may be distinguished (Carrillo-Hermosilla et al., 2010):

- design: reducing environmental impact throughout human actions, and reducing environmental impact of production and consumption by redesigning human made systems. Taking it into account, there can be identified three approaches to that issue: component addition, sub-system change, and system change;

- user: there can be identified two dimensions in this area: user development and user acceptance. Users are very important elements of eco-innovations development process, and also in identifying and making some improvements;

- product service: it underlines an importance of a supply chain perspective in environmental innovations. Two dimensions in this area can be identified: change in a product service deliverable, and change in a product service process;

- governance aspects: sometimes eco-innovations (when they implement radical changes) can be difficult to achieve because of some system barriers.

For environmental and business reasons, it is also crucial to increase the level of understanding of green consumer behaviors. Jansson (2011) tries to investigate factors driving and hampering consumers' behaviors regarding eco-innovation adoption. He distinguishes two perspectives: environmental and business. As regards environmental reasons, the key is to reduce negative consumption's effects to meet some goals put by the international community initiatives. The second standpoint is marketing and business. In this area, it is vital to fit the development of less ecologically harmful products with consumers' increased awareness 
and adoption of green lifestyles. It is very important, because without changing society's approach to environment friendly behaviors, the use of eco-products will be very little. To test factors driving and hindering eco-innovation adoption, Jansson (2011) conducted a research. He indicates some factors, which can act as drivers of eco-innovation adoption. These are social and personal norms, attitudes, novelty seeking, and how innovation attributes are perceived.

It is very important to introduce eco-innovation to the market in an appropriate way to achieve a success. Firms can face with a lot of unexpected circumstances and problems during this process. Pujari (2006) indicates five crucial elements for management of environmental new product development (ENPD) i.e.: upfront efficiency, cross-functional coordination, supplier involvement, design for environment/life cycle analysis, and market focus. Pujari (2006) goes out with some suggestions to each point. He suggests that a higher degree of each of those elements positively influences the ENPD performance. The study finds that some independent factors are really significant to market performance. These factors are: functional coordination, supplier involvement, life cycle analysis, and market focus. An appropriate understanding of activities mentioned above can help companies to better integrate environmental issues and develop eco-innovation products. By doing this, environmental innovations can deliver many benefits for companies and become a source of competitive advantage.

\section{Eco-innovations as a source of competitive advantage}

In the situation of an increased environmental pressure from external and internal stakeholders, innovative solutions are one of the best responses to that requirements and crucial components for increasing businesses' environmental performance (Buhl et al., 2016). Eco-innovations can be a source of many opportunities for companies. They can be identified as one of key factors for firms to achieve environmental sustainability (Pujari, 2006). Environmental innovations can be a source of competitive advantage for companies (Buhl et al., 2016). Green innovations, because of increased financial and institutional efforts they require, become a very significant element of enterprise's environmental, innovation and competitiveness strategies. They can entail 
a win-win situation and help firms to combine their competitiveness with environmental sustainability and to achieve expected growth (Ghisetti et al., 2015). Eco-innovations can give businesses advantages over their competitors, which can positively influence business performance, or positively affect firm's image (that enterprise can be perceived as environmentally friendly, innovative, and modern) what can also lead to many benefits, like e.g. an increased market share or competitive advantage.

Buhl et al. (2016) state that implementing eco-innovations may imply an environmental lead, which can determine a competitive advantage. Companies involved in environmental innovations activities can face some positive effects on environmental performance. Moreover, there can be identified positive influences on firms' financial performance. As it was mentioned in previous sections, Cheng et al. (2014) identify eco-organizational innovations as an innovation type having the strongest impact on business performance. Nevertheless, eco-product and eco-process innovations also have an influence on that. A positive impact on financial performance can be manifested throughout many different benefits. It is also very important that eco-innovations, driving environmental performance, strengthen enterprises' intangible assets (Buhl et al., 2016), such as company's reputation and image (Pujari, 2006), brand awareness and trust, and perceived quality (Buhl et al., 2016). It can also have a positive impact on customer satisfaction and attract new potential customers. A good image and being perceived as a socially responsible company can also lead to increase company's attractiveness as an employer. So, it can attract new employees to work for that firm, and increase its workers' productivity and organizational commitment. Furthermore, due to spillover effect, an enterprise can experience an increase in demand for its non eco-products. It leads to rise in sales revenues, market share (Buhl et al., 2016), and return on investment (Pujari, 2006). A very significant issue is that companies, introducing their eco-innovations into the market, benefit from the "first mover advantage" and can set prices (Buhl et al., 2016). Throughout its market newness and a higher technological level, innovation delivers some added value to customers. It is that because of its lower costs, reliability, technical performance, quality and novelty. Eco-innovation products usually have some unique features, which competitors' products lack. They offer some benefits and advantages to customers and they can meet customers' needs to a greater extent (Halila \& 
Rundquist, 2011). All of these benefits are a basis for achieving a competitive advantage (Buhl et al., 2016).

Nevertheless, to gain these benefits from eco-innovations and to achieve competitive advantage, companies have to face with some challenges connected with the market and consumer behaviors. First of all, they need to "identify and target customer segments that value green product attributes” (Buhl et al., 2016, p. 3). The most demanded products are those which meet yet unfulfilled needs (Halila \& Rundquist, 2011). Some customers are ready to buy and pay more for eco-products (Buhl et al., 2016). They can perceive higher prices of new eco-products as indicators of greater value in comparison to other products (Halila \& Rundquist, 2011). It is significant to identify target customers in an appropriate way, because they are different in the green niches market and in the mass market. Most of eco-innovators try to target green market niches, where customers favor green characteristics and benefits of products (Buhl et al., 2016). To sum up, it is crucial to gain benefits and competitive advantage from eco-innovations to develop products in a right way and appropriately identify target markets and customers. Thanks to that it can be a great driver for achieving and maintaining competitive advantage.

\section{Conclusions}

Summing up, eco-innovations are new solutions in the company's operations and the aim of the concept is to reduce the environmental impact, which is caused by production and consumption. Eco-innovations, including product innovation, process innovation, and organizational innovation, may lead both to incremental and radical changes in a company. Implementation of eco-innovations may be driven by demand/market factors, organizational capabilities or environmental regulations. Eco-innovations can have a strong impact on companies' business performance and contribute to developing company's competitive advantage over rivals. However, developing and implementing eco-innovations is challenging and firms need to pay particular attention while conducting such projects.

Summing up the findings, the limitations of the study process should be explained. Firstly, in order to meet the aim and objectives of the study, only one research method, i.e. systematic literature 
review, was applied. This method enables researchers to 'dive deeply' into the topic and analyze it thoroughly but is limited in regard to the number of publications taken for analysis. Thus, in future research, it is recommended to employ bibliometric methods relevant for mapping research fields such as research profiling (Porter et al., 2020) or science mapping (Zupic \& Čater, 2015). Bibliometric methods provide opportunity to include into quantitative analysis numerous samples of publications and identify intellectual and conceptual structures of research fields. Recent studies published in the Journal of Corporate Responsibility and Leadership (Lis, 2019a, 2019b, 2020) provide good examples and role models for such studies. Secondly, the research sampling process was conducted with the use of one database i.e. Scopus only. As Scopus is biased towards articles written in English, there is high risk that some relevant studies written in languages other than English or not indexed in the Scopus database could have been omitted and not analyzed in this article. Thus, it can be recommended for further studies to extend the search for relevant literature sources and include other databases of research literature. Thirdly, there is a need for empirical studies, both of qualitative and quantitative character to explore the concept of eco-innovations and explain its relationships with other variables.

\section{References}

Buhl, A., Blazejewski, S., \& Dittmer, F. (2016). The more, the merrier: Why and how employee-driven eco-innovation enhances environmental and competitive advantage. Sustainability (Switzerland), 8(9).

Carrillo-Hermosilla, J., Del Río, P., \& Könnölä, T. (2010). Diversity of eco-innovations: Reflections from selected case studies. Journal of Cleaner Production, 18(10-11), 1073-1083.

Cheng, C.C.J., Yang, C.-L., \& Sheu, C. (2014). The link between eco-innovation and business performance: A Taiwanese industry context. Journal of Cleaner Production, 64, 81-90.

Czakon, W. (2011). Metoda systematycznego przeglądu literatury. Przeglq̨d organizacji, 3, 57-62.

Czerniachowicz, B., Lis, A., \& Wieczorek-Szymańska, A. (2017). The relationships between leadership and corporate social responsibility: Systematic literature review. Journal of Corporate Responsibility and Leadership, 4(3), 9-23.

Doran, J., \& Ryan, G. (2012). Regulation and firm perception, eco-innovation and firm performance. European Journal of Innovation Management, 15(4), 421-441.

Europa INNOVA (2006). Thematic workshop, lead markets and innovation. Munich, Germany, June 2006. 
European Commission (2007). Competitiveness and Innovation Framework Pogramme (2007-2013). Brussels.

European Commission (2008). Call for proposals under the eco-innovation 2008 programme. DG Environment. Retrieved from: https://ec.europa.eu/environment/ ecoap/ (accessed 10 February 2018).

Fussler, C., \& James, P. (1996). Eco-innovation: A Breakthrough Discipline for Innovation and Sustainability. London: Pitman Publishing.

Ghisetti, C., Marzucchi, A., \& Montresor, S. (2015). The open eco-innovation mode. An empirical investigation of eleven European countries. Research Policy, 44(5), 1080-1093.

Halila, F., \& Rundquist, J. (2011). The development and market success of ecoinnovations: A comparative study of eco-innovations and "other" innovations in Sweden. European Journal of Innovation Management, 14(3), 278-302.

Horbach, J., Oltra, V., \& Belin, J. (2013). Determinants and specificities of ecoinnovations compared to other innovations - An econometric analysis for the French and German industry based on the community innovation survey. Industry and Innovation, 20(6), 523-543.

Jansson, J. (2011). Consumer eco-innovation adoption: Assessing attitudinal factors and perceived product characteristics. Business Strategy and the Environment, 20(3), 192-210.

Józefowicz, B. (2017). Diversity management and trust: Systematic literature review. Journal of Corporate Responsibility and Leadership, 4(4), 51-68.

Kemp, R., \& Pontoglio, S. (2007). Workshop conclusion on typology and framework: Measuring eco-innovation. Retrieved from https://www.researchgate.net/profile/ Maj_Andersen/publication/238691195_This_report_describes_the_outcomes_of_ the_first_workshop_of_MEI_where_researchers_met_with_people_from_the_ advisory_board_members_and_scientific_officer_Venue_AM_-_SDME_building_ of_DG_Research_Square_/links/542e82960cf29bbc126f2703.pdf (accessed 10 February 2018).

Kesidou, E., \& Demirel, P. (2012). On the drivers of eco-innovations: Empirical evidence from the UK. Research Policy, 41(5), 86--870.

Lis, A. (2019a). Leadership and corporate social responsibility: Mapping the conceptual structure of research. Journal of Corporate Responsibility and Leadership, 6(1), $7-21$.

Lis, A. (2019b). Case study methodology in research on corporate social responsibility: General publication profiling and identifying research contexts. Journal of Corporate Responsibility and Leadership, 6(2), 7-28.

Lis, A. (2020). Case study methodology in research on corporate social responsibility: Identifying core references with direct citation analysis. Journal of Corporate Responsibility and Leadership, 7(1), 7-20.

Lis, A., \& Sudolska, A. (2018). W poszukiwaniu typologii innowacji społecznie odpowiedzialnych: Mapowanie pola badawczego. Studia i Prace Wydziału Nauk Ekonomicznych i Zarzq̨dzania Uniwersytetu Szczecińskiego, 52(2), 115-125.

Porter, A. L., Kongthon, A., \& Lu, J.-C. C. (2002). Research profiling: Improving the literature review. Scientometrics, 53(3), 351-370.

Pujari, D. (2006). Eco-innovation and new product development: Understanding the influences on market performance. Technovation, 26(1), 7-85. 
Ślęzak, M., \& Jagielski, M. (2018). Manifestations and measures of frugal innovations. Journal of Corporate Responsibility and Leadership, 5(4), 81-104.

Zupic, I., \& Čater, T. (2015). Bibliometric methods in management and organization. Organizational Research Methods, 18(3), 429-472. 
